\title{
Magyar páncélosok alkalmazása a II. világháborúban m.resz
}

\section{A DÉLVIDÉKI HADMŰVELETEK}

Németország 1941. április 6-án megtámadta Jugoszláviát. A németek egy gyors hadjárattal akarták a Barbarossa hadművelet előtt stabilizálni a balkáni hátországukat. (Ezt a brit erők Görögországban végrehajtott partraszállása is veszélyeztette.)

Magyarország a támadó német hadsereg egyik felvonulási, gyülekezési körzete volt. A Magyar Királyi Honvédségnél is elrendelték a részleges mozgósítást és a harckészültséget. A német támadást követően számos légitámadás érte a határ menti településeket. $A$ német támadás súlya alatt a több nemzetiségű jugoszláv állam szétesett. A horvátok kikiáltották az önáló Horvátországot. A magyar kormány arra hivatkozva, hogy a Vajdaságban hatalmi vákuum keletkezett, ami veszélyezteti az ott élő magyar kisebséget, elrendelte a honvédség bevetését.

A magyar honvédség alakulataiból, a 3. hadsereg (I., IV., V. hadtest), a gyorshadtest, a légierő kijelölt alakulatai és a folyamőrség vett részt az 1941. április 11-én meginduló hadmúveletekben. A gyorshadtest az 1. és 2. gépkocsizó lövész- és az 1. és 2. lovasdandárból állt. A gyors/páncélos csapatok éppen átszervezés alatt álltak, amikor felriasztották őket. Éppen ekkor kezdődött meg az új harckocsizászlóaljak megszervezése.

8. ábra. Az 1. felderítő zászlóalj páncélgépkocsi-századának 39M Csaba páncélgépkocsija és civilek magyar zászlóval a délvidéki hadművelet során, 1941. áprilisa

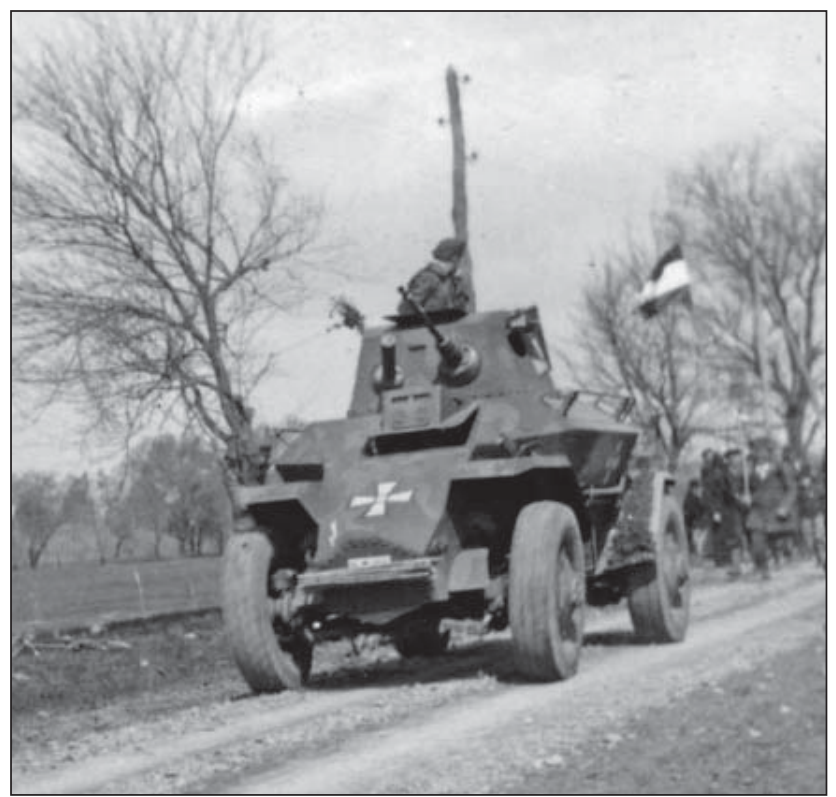

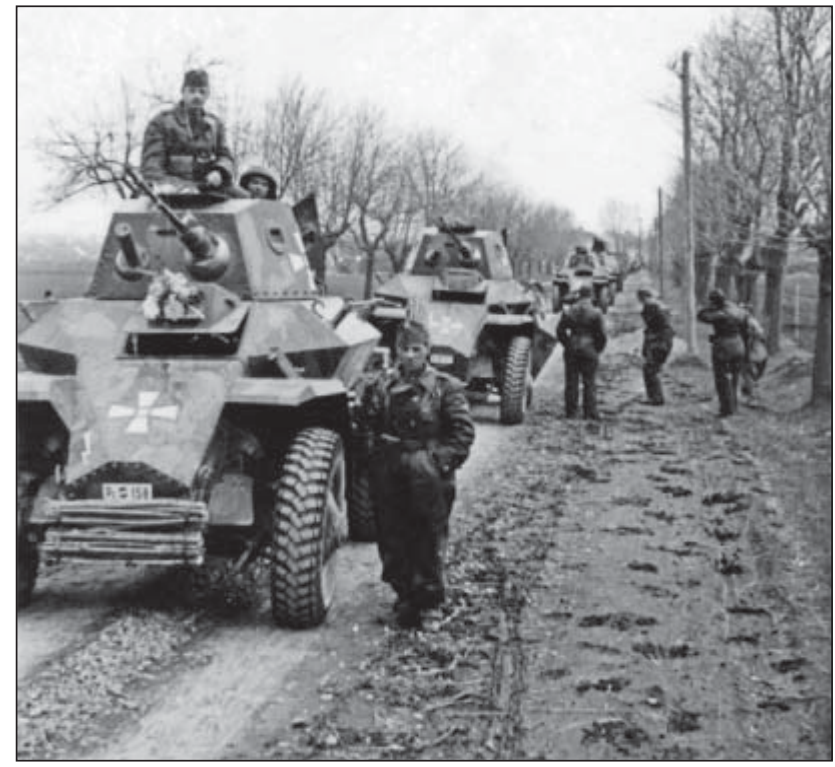

9. ábra. Az 1. felderítő zászlóalj egyik Csaba páncélgépkocsiszakasza indulásra készen. A virágcsokor az első jármúvön, nem volt tipikus ebben a hadmüveletben

A lovas páncéloszászlóaljak megkapták a két-két kis harckocsiszázadaikat, de hiányoztak a 38M Toldi könnyű harckocsiszakaszok. Az elvonuló csapatok a mozgósítás akadozása, a hiányos fegyverzet, felszerelés miatt csak csökkentett harcértéket képviseltek.

A 2. gépkocsizó lövészdandár hadrendjéből 10 db könynyű harckocsi, $8 \mathrm{db}$ páncélgépkocsi, $135 \mathrm{db}$ motorkerékpár és $21 \mathrm{db}$ gépjármű hiányzott. A 2. felderítő zászlóalj gépjárművek hiánya miatt a gépkocsizó lövészszázadát és az árkászszakaszát nem tudta mozgósítani, ezek nélkül vonult el.

Az 1. lovas páncéloszászlóalj a páncéltörő ágyús, távbeszélő-, árkász- és könnyű harckocsiszakaszok nélkül indult a frontra. A 2. lovas páncéloszászlóaljnak 3 kis harckocsi, egy páncélgépkocsi-százada volt, a páncéltörő ágyús szakasznak viszont csak $1 \mathrm{db} 36 \mathrm{M}$ lövege volt. A kis harckocsiszázadok $18 \mathrm{db} 35 \mathrm{M}$ FIAT Ansaldo kis harckocsival és $3 \mathrm{db} 38 \mathrm{M}$ Toldi könnyü harckocsival rendelkeztek.

A szerb-magyar határon a jugoszláv hadsereg megerődített határőrposztokat és kis erődökből álló védelmi vonalat épített ki az évek során. A magyar előrenyomulás idején azonban a reguláris jugoszláv alakulatok nagyrészt elhagyták a védelmi vonalakat. A magyar csapatok kisebb harcok árán birtokba vették azokat.

1941. április 11-én három felderítőcsoportot hoztak létre és alkalmaztak Hercegszántó körzetében. Az 1. felderítő- 


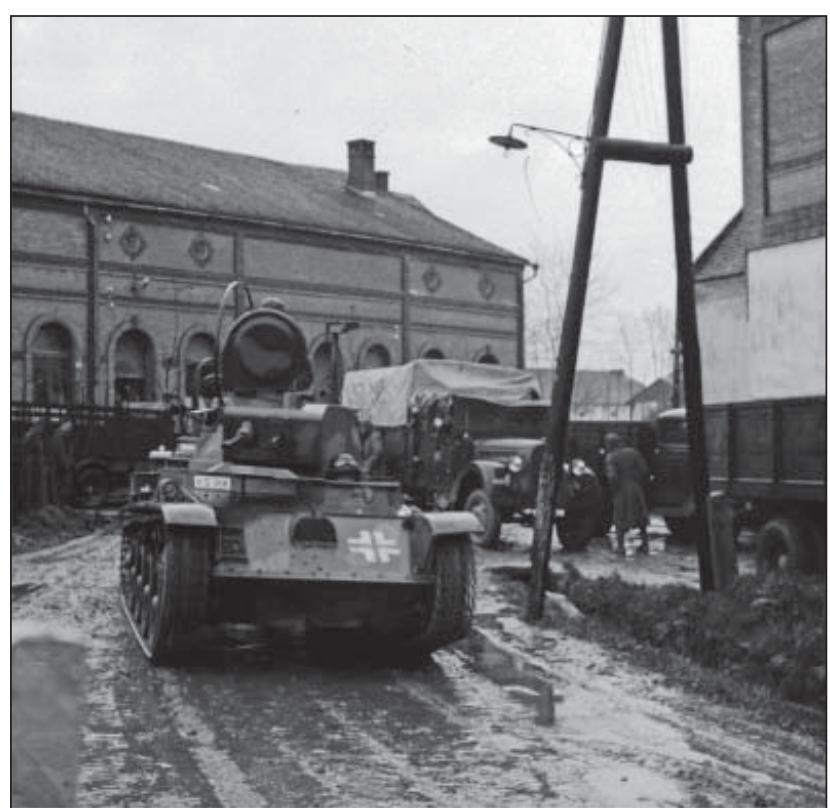

10. ábra. A 2. felderítő zászlóalj 38M Toldi könnyú harckocsija útban a frontra, mögötte Ford tehergépkocsik

zászlóalj az 1. gépkocsizó lövészdandár élén haladt az előrenyomulás során. A felderítő-zászlóaljat megerősítették egy gépkocsizó lövészszázaddal, egy gépvontatású könynyű tarackos üteggel (a 9. kerékpáros zászlóalj állományából), egy-egy géppuskás és árkászszakasszal.

Az 1. lovas páncéloszászlóaljat (egy-egy könnyű, kis harckocsi és páncélgépkocsi század) megerősítették egy gépvontatású könnyű tarackos üteggel (37M 10,5 cm). Az előrenyomuló könnyű harckocsi és páncélgépkocsi-századok a jugoszláv erődítéseket elhagyatva találták.

A 2. lovas páncéloszászlóalj katonái szintén üres erődöket foglaltak el Bajmoktól keletre.

A 2. gépkocsizó lövészdandár parancsnoka, Vörös János ezredes április 12-én két harccsoportot hozott létre a dandár egységeiből. A Sándor harccsoport, (Sándor alezredes a 4. gépkocsizó lövészzászlóalj parancsnoka volt) a 4. gépkocsizó lövész-, a 2. felderítő zászlóaljakból, a 12. kerékpáros zászlóalj gépvontatású könnyű tarackos ütegéből, 2 db 36M 40 mm-es Bofors gépágyúból és egy árkászsza-

11. ábra. Ansaldo kis harckocsiszakasz vonul át egy délvidéki falun 1941 áprilisában

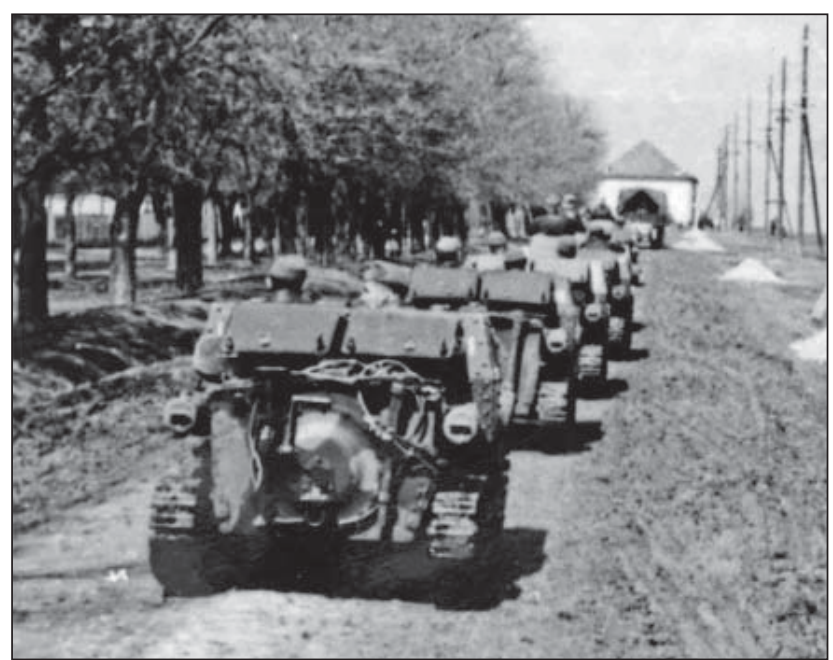

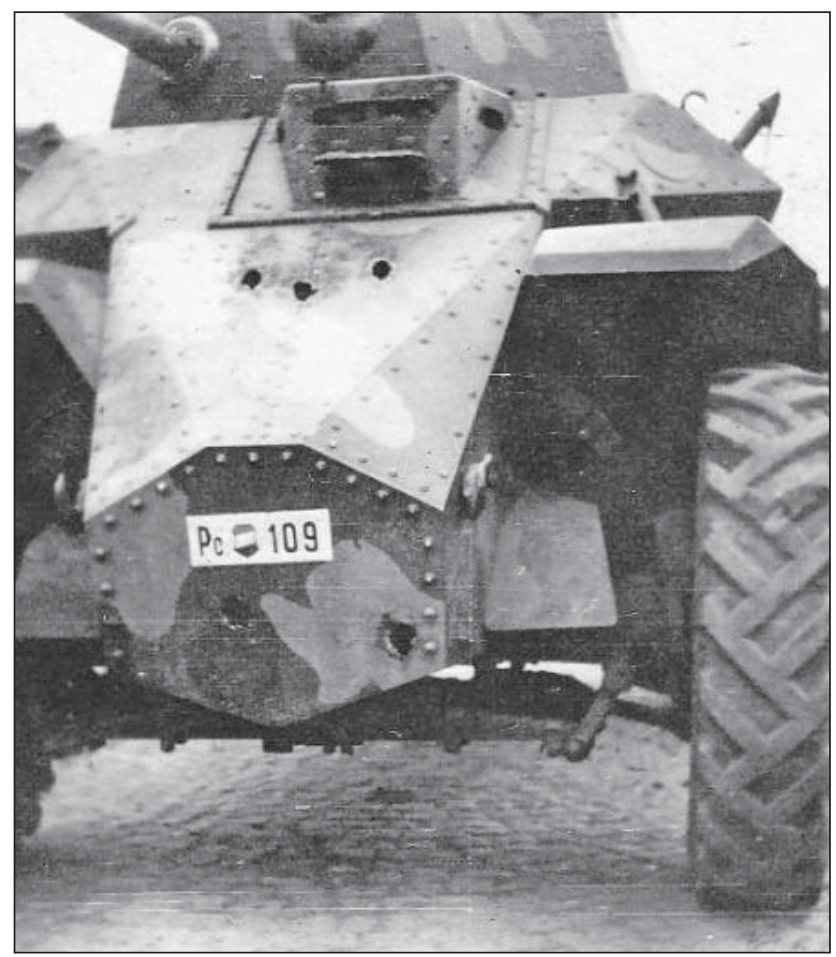

12. ábra. Az 1. lovas páncéloszászlóalj 1941. április 13-án kilőtt 39M Csaba páncélgépkocsija. $A$ jármú 5 találatot kapott egy $37 \mathrm{~mm}$-es páncéltörö ágyútól

kaszból állt. A Sándor harccsoport a dandár első lépcsőjében került harcba vetésre azzal a feladattal, hogy foglalja el Szenttamást, vegye birtokba a szenttamási hidat és törjön elöre Újvidék felé.

A második, Benda harccsoport (Benda alezredes a 12. kerékpáros zászlóalj parancsnoka volt) az 5 . és 6 . gépkocsizó lövész-, 12. kerékpáros zászlóaljból, a 2. gépvontatású könnyű tarackos tüzérosztályból és két árkászszakaszból állt. A Benda harccsoportot a dandár második lépcsőjében vetették be. Kishegyes-Topolya irányába kellett előrenyomulnia.

Az utak rossz minősége és az esőzések miatt a csapatok csak lassan tudtak előrenyomulni. Az 1. gépkocsizó lövészdandár április 12-én kezdte meg az előrenyomulást. $A z$ 1. és 2. gépkocsizó lövészzászlóaljak gépjárműveken elérték Zombort. De túl későn ahhoz, hogy megakadályozzák a zombori híd felrobbantását a Ferenc-csatorna felett. A 3. gépkocsizó lövészzászlóalj alegységei gyalogosan nyomultak előre és közben összecsaptak a szerb erőkkel Küllőd térségében. A honvédek 42 foglyot ejtettek és $5 \mathrm{db}$ löveget zsákmányoltak.

Április 12-e reggelén az 1. felderítő-zászlóalj könnyűharckocsi-százada szerb csapatokba ütközött Zombor térségében. Rövid és heves összecsapás során a magyar csapatok 74 szerb foglyot ejtettek, 4 db páncéltörő ágyút és $6 \mathrm{db}$ géppuskát zsákmányoltak. A felderítő-zászlóalj ugyanaznap jelentős szerb erőkkel ütközött meg Topolyánál, a Ferenc-csatorna mentén.

Két db 39M Csaba páncélgépkocsi is részt vett a felderítésben, Sándor Mihály hadapród őrmester parancsnoksága alatt. A páncélgépkocsik egy jelentősebb szerb erőt derítettek fel. Az őrmester az egyik páncélgépkocsit viszszaküldte jelentéstételre. Ez elárulja azt is, hogy a rádiókapcsolat nem nagyon működött a csapatok és a parancsnokságok között. A másik Csaba páncélgépkocsival oldalba támadta a szerb erőket. A támadás és a heves géppus- 


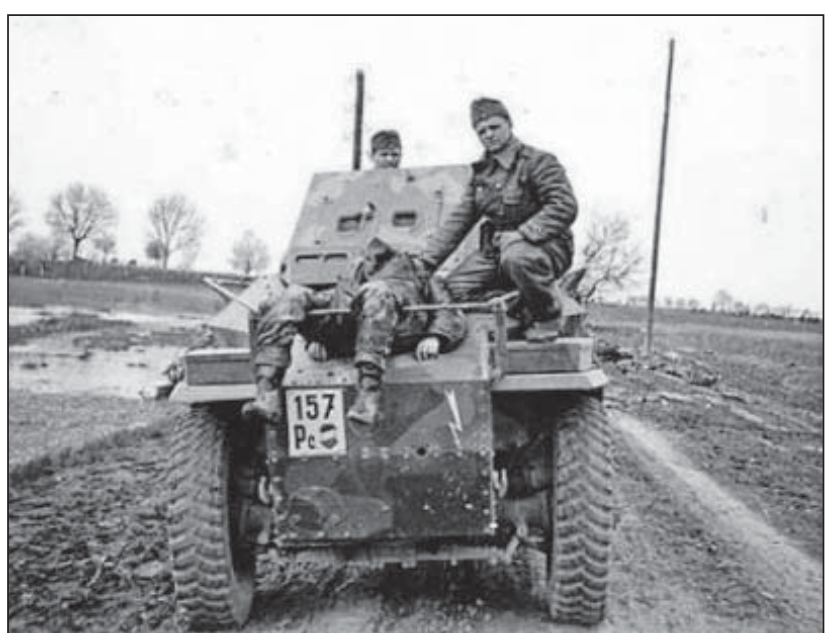

13. ábra. Az 1. felderítő-zászlóaljhoz tartozó Alexy Andor zászlós holtteste a $39 \mathrm{M}$ Csaba páncélgépkocsiján

ka- és nehézpuskatűz meglepte a szerbeket, akik a védekezés helyett a visszavonulást választották. Több száz szerb pedig inkább a megadást választotta.

Sándor Mihály hadapród örmester egy hasonló vállalkozást hajtott végre április 15-én Bácsszőregnél, ahol bekerített huszárokat szabadított ki. Ezekért a haditettekért Nagy Ezüst Vitézségi Éremmel tüntették ki.

Az előrenyomulás során a dandárok és a gyorshadtest közötti híradást nem sikerült fenntartani. A gyorshadtest parancsnokának, Miklós Béla vezérőrnagynak nem volt információja a 2. lovas- és 2. gépkocsizó lövészdandárok előnyomulásáról. Ezért utasította az 1. gépkocsizó lövészdandárt, hogy változtassa meg a támadási irányát és forduljon Újvidék irányába.

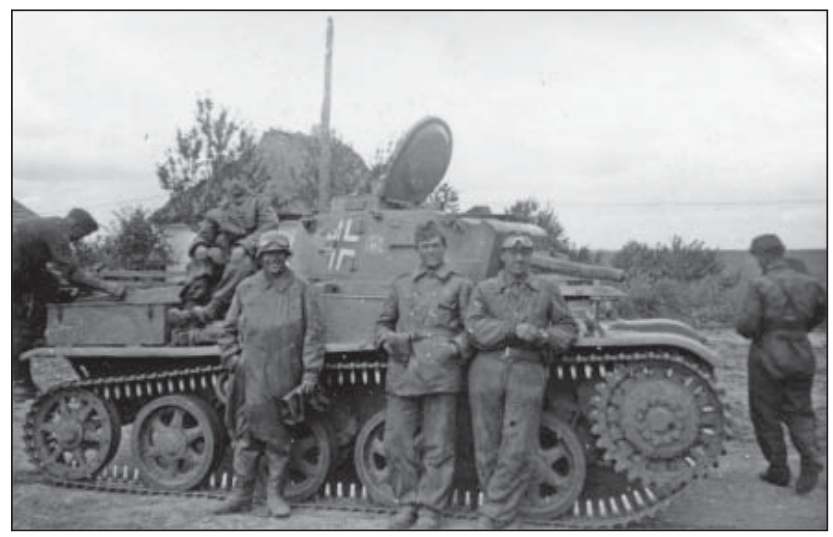

15. ábra. 38M Toldi harckocsi és kezelői egy érdeklődő német motorkerékpáros katonával a Délvidéken

A 2. lovasdandár feladata volt a szenttamási híd elfoglalása április 12-13-án. Kozocsa alezredes (a 2. lovas páncéloszászlóalj parancsnoka) parancsnoksága alatt létrehozott harccsoport, 2. lovas páncéloszászlóalj, egy gépvontatású könnyű tarackos üteg és egy fél árkászszázad kapta feladatul a híd elfoglalását.

A magyar csapatok, követve a visszavonuló szerb erőket, Topolya irányából támadtak Szenttamás felé. 1941. április 13-án a lovas páncéloszászlóalj egy felderítőjárőrt küldött Szenttamás felderítésére. A 2 db 39M Csaba páncélgépkocsi Béldy László főhadnagy parancsnoksága alatt közelítette meg a megerősített falut. A hídnál egy jól álcázott szerb 37 mm-es páncéltörő ágyú tüzébe került a két magyar páncélgépkocsi. A Csabák számos találatot kaptak és 6 fő elesett, köztük Béldy főhadnagy is.

A szerb páncéltörő ágyút, közvetlen irányzással Makláry László főhadnagy egy nyílt tüzelőállásba vontatott,

14. ábra. 38M Toldi könnyű harckocsi vonul át Vukovár utcáján; 1941 áprilisa

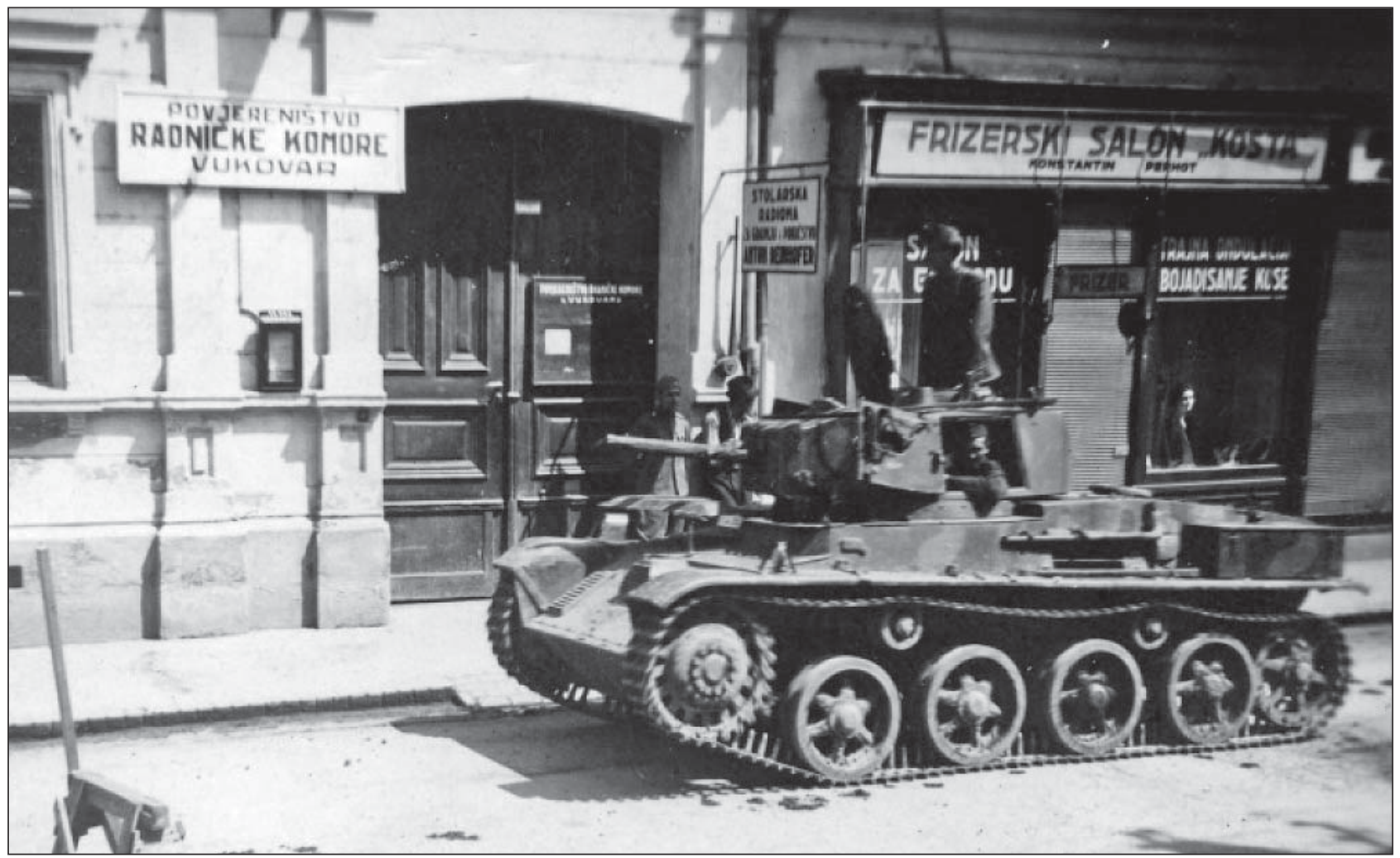




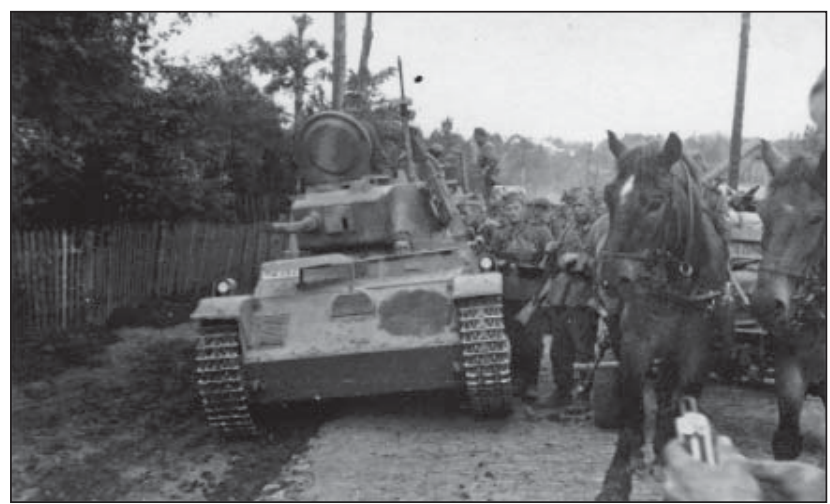

16. ábra. Pihenő német gyalogság és magyar harckocsizók 38M Toldi könnyű harckocsival. A géppuska légvédelmi állványra helyezve, Délvidék 1941.

10,5cm-es könnyű tarackkal lőtte ki 500 m-ről. A kilőtt Csaba páncélgépkocsikat később kijavították.

Amikor a Sándor harccsoport is megérkezett Szenttamásra, heves utcai harcok törtek ki. A 4/1. üteg egyik 10,5 cm-es könnyű tarackja nyílt tüzelőállást foglalt a hídfeljáróval szemben és közvetlen irányzással kilőtte a hidat őrző bunkereket. Ez lehetővé tette, hogy a magyar csapatok hatástalanítsák a hídra szerelt tölteteket, ezzel megóvva a hidat a robbantástól. Szenttamás elfoglalása után a Sándor csoport Újvidék északi széle felé nyomult előre.

A 2. lovas páncéloszászlóalj egyik kisharckocsi-százada felderítést hajtott végre a Szabadka térségében lévő szerb bunkerek közelében. A századparancsnok 38M Toldi parancsnoki könnyű harckocsija aknára futott és a robbanás letépte az egyik lánctalpat. A szerb állások egyébként üresek voltak.

1941. április 13-án, Petrőcz térségében az 1. felderítőzászlóalj felderítői rajtaütöttek egy visszavonuló szerb gyalogezred egységein. A felderítő-zászlóalj zöme a páncélgépkocsi-század és egy könnyű tarackos üteg támogatásával, Petrőcz és Dunagálos térségében oldalba támadták a szerb gyalogságot. A magyar csapatok egy rövid, de heves tűzcsapása nyomán a szerbek megadták magukat. A felderítő-zászlóalj 30 szerb tisztet és 1000 fő legénységi állományú katonát ejtett foglyul, és délután 4 órakor elérte Újvidéket.

A kapitulált szerb alakulat lefegyverzésében részt vett Alexy Andor zászlós, a páncélgépkocsi század egyik szakaszparancsnoka. Alexy zászlós kiszállt a Csaba páncélgépkocsijából, hogy ellenőrizze a szerb katonák lefegyverzését. Az egyik lefegyverzésre váró szerb tiszt lelőtte a magyar zászlóst. A merénylőt a Csaba páncélgépkocsi toronygéppuskája lelőtte.

1941. április 13-án, a kora esti órákra az 1. gépkocsizó lövészdandár zöme megszállta Újvidéket. A városban viszszamaradt szerb csetnikek tüzet nyitottak a bevonuló magyar csapatokra. A magyar csapatok nem voltak kiképezve gerillák elleni harctevékenységre. A magyar csapatok pánikba estek a lesből lövöldöző csetnikektől. Megszűnt a tűzfegyelem, a katonák ész nélkül tüzet nyitottak minden vélelmezett ellenséges mozgásra, tüzelőállásra. A magyar veszteségek zöme abból következett, hogy a honvédek egymásra lőttek. A harcok másnap, április 14-én is folytan tódtak, a SOPRON őrnaszád is tűztámogatásban részesítette az Újvidéken harcoló magyar csapatokat.

A 2. lovasdandár törzse, a 16. kerékpáros zászlóalj és az 5. tüzérosztály Szenttamáson éjszakázott április 13-ról 14-re virradóra. Az 1. huszárezred Bácsfeketehegy, a 2. huszárezred Óbecse térségében gyülekezett.

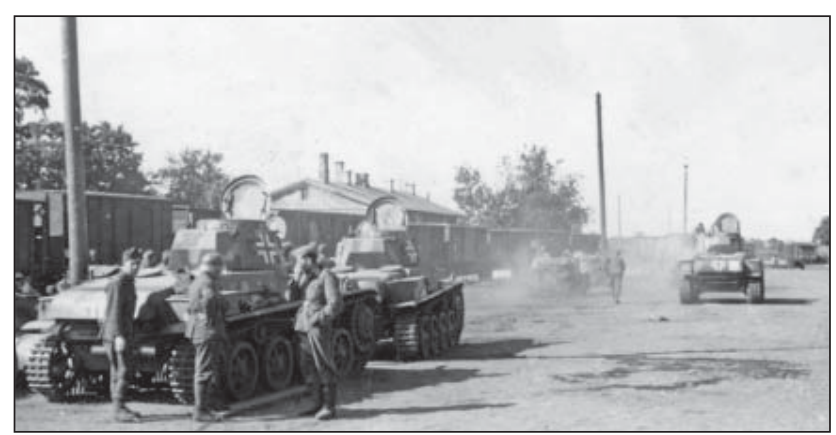

17. ábra. Toldi és Ansaldo harckocsik bevagonírozása a hadjárat végén; Délvidék, 1941.

$A z$ 1. lovasdandár megkésve érkezett a gyülekezési körzetébe Bajmók-Topolya térségébe. A 10. kerékpáros zászlóalj Ószer térségében lépett harcba. A magyar csapatok április 13-14-én visszafoglalták a Délvidéket.

1941. április 14-étől a gyorshadtest gépkocsizó lövészdandárjait a német Kleist páncélos csoportnak rendelték alá. A jugoszláv hadjárat gyors lezárása miatt azonban a gépkocsizó lövészdandárok más feladatot kaptak, EszékVinkovci-Vukovár térségét kellett biztosítaniuk.

A hadműveletek során a honvédség 5 tisztje és 60 katonája halt hősi halált, 3 tiszt és 239 fő legénységi állományú tagja sebesült meg. Az elesett 5 tiszt közül két fő, Béldy László főhadnagy és Alexy Andor zászlós a páncéloscsapatok állományába tartoztak.

\section{FORRÁSOK}

Babucs Zoltán: Jászsági honvédek a II. világháborúban, I. A jászberényi harckocsi zászlóalj története a II. világháborúban, 2000;

Babucs Zoltán - Maruzs Roland: „Jász vitézek rajta, előre!” A jászberényi kerékpáros és harckocsizó zászlóalj története 1920-1944, Puedlo;

Bíró Ádám - Éder Miklós - Sárhidai Gyula: A Magyar Királyi Honvédség külföldi gyártású páncélos harcjárművei 1920-1945, Petit Real, 2006;

Bíró Ádám - Éder Miklós - Sárhidai Gyula: A Magyar Királyi Honvédség hazai gyártású páncélos harcjármüvei 1920-1945, Petit Real, 2012;

Bombay László - Gyarmati József - Turcsányi Károly: Harckocsik 1916-tól napjainkig, Zrínyi, Budapest. Bonhardt Attila - Sárhidai Gyula - Winkler László: A Magyar Királyi Honvédség fegyverzete 1919-45 part 1, Zrínyi, 1992;

Dombrády Loránd -Tóth Lajos: Magyar Királyi Honvédség 1919-45, Zrínyi, 1987;

Dombrády Loránd: A magyar gazdaság és a hadfelszerelés, 1938/44, Akadémia, 1981;

Páncélos csapatok 60. évfordulója, HM, 1996;

Számvéber Norbert: Páncélosok a Felvidéken, Puedlo;

Sőregi Zoltán - Végső István: Gyorsan, bátran, hűséggel, A m. kir. „Balogh Ádám” 15. honvéd kerékpáros zászlóalj története, Timp Kiadó, 2009;

Horváth Csaba: A Gyorshadtest felderítő szolgálata ZMKA Akadémiai Közlemények;

Dombrándy Loránd: A horthysta katonai vezetés erőfeszítései a páncélos fegyvernem megteremtésére, HK 1969/2, 1970/4;

Dr. Varga D. József: Magyar autógyárak katonai járművei Maróti, 2008;

Csaba Becze: Magyar steel, MashroomPublication, 2006. 